\section{Hvordan snakke med familien om pasientens psykiske lidelse?}

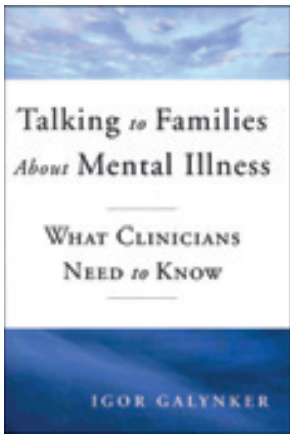

Igor Galynker

Talking to families about mental illness

What clinicians need to know. 270 s. New York, NY: W.W. Norton, 2010. Pris USD 33

ISBN 978-0-393-70600-0

Familien til psykiatriske pasienter kan fungere både som stressorer og som viktige støttespillere for så vel behandlere som pasienter. Manglende samarbeid med familien kan både øke dennes stressnivå og derved føre til flere pasienter, og det kan medføre at pasienten mister viktige medhjelpere $i$ en rehabiliteringsfase eller under en kronisk sykdom. I 1970- og 80-årene la vi derfor stor vekt på å forstå hvordan familien påvirket pasientens psykiske lidelse på godt og vondt, og hvordan den best kunne hjelpes til å hjelpe pasienten på en konstruktiv måte. Dessverre er familieperspektivet på psykiske lidelser kommet i bakgrunn de fleste steder, til tross for at «retningslinjene» forventer en familiekontakt. En av årsakene kan være at utviklingen av ulike former for spesifikk familieterapi har medført at man feilaktig tror at familieperspektivet bare er relevant $i$ «familieterapi» og ikke også i all form for psykiatrisk diagnostikk og behandlingsplanlegging.

Den foreliggende boken retter opp denne feiloppfatningen på en glimrende måte. Forfatteren gir en jordnær, nyansert og klinisk relevant gjennomgang av hvordan man som lege kan (og bør!) snakke med de pårørende om en pasients psykiske lidelse, diagnose, enkeltsymptomer, selvmordstanker, årsaksforhold, sykdomsforløp, ulike former for behandling, prognose, familiens bidrag til å hjelpe, osv. Teksten er full av korte og illustrerende eksempler på hva forfatteren konkret sier om ulike emner til et familiemedlem.

I den første halvdelen av boken gjennomgås disse emnene på tvers av diagnoser. I den andre halvdelen gjennomgås de enkelte diagnosegruppene: schizofreni, bipolare lidelser, alvorlig depresjon, angstlidelser og personlighetsforstyrrelser. Og forfatteren drøfter også hva man kan si om pasienters muligheter for videre utdanning, stressmestring, jobb og familieplanlegging. En styrke ved boken er at den også på alle punkter refererer kort til aktuell, empirisk kunnskap på området. Lesingen gir derved også en konsentrert klinisk oppdatering som er meget verdifull for så vel fastleger som psykiatere (og pasienter og familier).

Hvis du skulle bestemme deg for å inkludere familien og familieperspektivet $\mathrm{i}$ din behandling av pasienter med alle slags psykiske lidelser, er denne lettleste og svært relevante boken et funn.

\section{Per Vaglum}

Avdeling for medisinske atferdsfag

Institutt for medisinske basalfag

Universitetet i Oslo

\section{Neppe av interesse for medisinere}

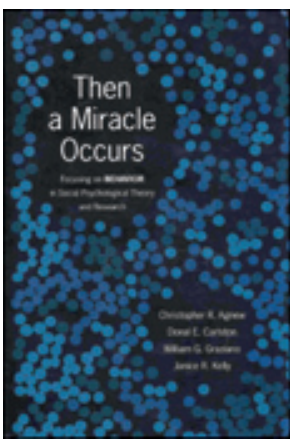

Christopher R. Agnew, Donal E. Carlston, William G. Graziano et al.

\section{Then a miracle occurs}

Focusing on behavior in social psychological theory and research. 451 s, tab, ill. Oxford: Oxford University Press, 2010. Pris GBP 38 ISBN 978-0-19-537779-8

Forfatterne er fremstående psykologer ved amerikanske universiteter. Målgruppen er åpenbart psykologer med interesse for forskning.

Det er tre hovedbolker. Først diskuterer forfatterne atferd i sosialpsykologisk forskning og teori, dernest atferd og intraindividuelle prosesser og endelig atferd og interindividuelle prosesser.

Forfatterne hevder at betydelige fremskritt er gjort innen sosialpsykologien gjennom studier av indre kognitive, affektive og motivasjonelle sider av atferd, men altfor lite er gjort for å studere selve den ytre atferden. Dessuten er den atferden som er studert, ofte av dramatisk karakter, som aggresjon eller altruistiske handlinger. Mens det man burde utforske, var atferd i dagliglivet.

Det er mange måter å måle atferd på. Direkte inspeksjon av atferden er det mest naturlige. Men den vanligste metoden i sosialpsykologien har likevel vært selvrapportering. I nevrovitenskap og kognitiv psykologi har man vært opptatt av å forstå hvordan hjernen og sinnet fungerer, men man har vært lite opptatt av de aktivitetene som folk flest driver med til daglig.

Sosialpsykologien og personlighetspsykologien har bygd på spørreskjema mer enn på direkte observasjon av atferd. Man blir spurt om hva man tenkte, hvordan man følte, og hvorfor man gjorde det man gjorde. Men tar ikke folk feil når de forsøker å analysere grunnene til sine handlinger?

Et eksperiment i 1970-årene viste klart diskrepansen mellom aktuell og hypotetisk atferd. Eksperimentet gjaldt en person på gaten som hadde vært utsatt for en ulykke, og som ba om penger til medisinsk behandling. De fleste forsøkspersonene sa at de ville gi rikelig til mannens behandling. Men da eksperimentet ble utført i virkeligheten med de samme forsøkspersonene, viste det seg at donasjonene var meget små, ofte bare knapt ti cent $\mathrm{i}$ visse tilfeller.

I senere år har grunnene til å tvile på selvrapportering og behovet for å observere virkelig atferd økt. Studier har nemlig vist hvor unøyaktig folks prediksjon er når det gjelder utsagn om hvordan de vil reagere i bestemte situasjoner.

Boken er interessant, men vil nok være av begrenset nytte for de fleste medisinere.

\section{Einar Kringlen}

Psykiatrisk institutt

Universitetet i Oslo 